\title{
A NEED ANALYSIS OF STEM-INTEGRATED FLIPPED CLASSROOM E-MODULE TO IMPROVE CRITICAL THINKING SKILLS
}

\author{
Reni Dwi Puspitasari ${ }^{1 *}$, Kartini Herlina², Agus Suyatna ${ }^{3}$ \\ ${ }^{1,2,3}$ Department of Physics Education, Postgraduate Program, Universitas Lampung, Indonesia \\ *Corresponding author: renidps53@gmail.com
}

\begin{tabular}{|c|c|}
\hline Article Info & ABSTRACT \\
\hline Article history: & ssroom and STEM learning approach \\
\hline Received: March 28, 2020 & $\begin{array}{l}\text { has become one of the interesting studies in Education. Various } \\
\text { researches were conducted to determine their impact on learning. }\end{array}$ \\
\hline Accepted: July 30, 2020 & This research is a descriptive survey conducted to determine the \\
\hline Published: July 31, 2020 & $\begin{array}{l}\text { needs of teachers and students about e-module with the STEM } \\
\text { integrated flipped classroom. Data were collected using a }\end{array}$ \\
\hline & $\begin{array}{l}\text { questionnaire with } 15 \text { respondents who work as physics teachers in } \\
\text { Lampung Province and } 30 \text { respondents from grade XI students in }\end{array}$ \\
\hline Crit & one of the high schools in Bandar Lampung. Based on the survey \\
\hline classroom & results, we concluded that (1) $86 \%$ of physics teachers stated that \\
\hline STEM & $\begin{array}{l}\text { they needed a STEM-integrated flipped classroom e-module, and } \\
\text { (2) } 78 \% \text { of students stated that they were interested in learning by } \\
\text { using a STEM-integrated flipped classroom e-module. So it is clear } \\
\text { that physics teachers and students in Lampung need e-modules } \\
\text { with a flipped classroom approach and integrated STEM. }\end{array}$ \\
\hline
\end{tabular}

\section{ANALISIS KEBUTUHAN TERHADAP E-MODUL FLIPPED CLASSROOM TERINTEGRASI STEM DALAM MENINGKATKAN KETERAMPILAN BERPIKIR KRITIS}

Kata Kunci:
Berpikir Kritis
Flipped Classroom
STEM

Kata Kunci:

Flipped Classroom STEM \begin{abstract}
ABSTRAK
Beberapa tahun ini, pendekatan flipped classroom dan STEM menjadi salah satu kajian yang menarik dalam Pendidikan. Berbagai penelitian dilakukan untuk mengetahui dampaknya terhadap pembelajaran. Penelitian ini merupakan sebuah survey deskriptif yang dilakukan untuk mengetahui kebutuhan guru dan siswa tentang e-modul dengan pendekatan flipped classroom yang terintegrasi STEM. Data dikumpulan dengan menggunakan angket/kuesioner dengan jumlah responden 15 guru fisika di Provinsi Lampung dan 30 siswa kelas XI di salah satu SMA di Bandar Lampung. Berdasarkan hasil survey, kami menyimpulkan bahwa (1) $86 \%$ guru fisika menyatakan bahwa mereka membutuhkan e-modul dengan pendekatan flipped classroom dan terintegrasi STEM (2) 78\% Siswa menyatakan bahwa mereka tertarik untuk belajar dengan menggunakan e-modul dengan pendekatan flipped classroom dan terintegrasi STEM. Sehingga jelas bahwa guru fisika dan siswa di Lampung membutuhkan e-modul dengan pendekatan flipped classroom dan terintegrasi STEM.
\end{abstract}




\section{INTRODUCTION}

One of the challenges of education in this era is building 21st century skills. These skills are known as information \& communication technology literacy skills, critical thinking skills, problem solving skills, effective communication skills, and collaborate skills. 21st Century skills develop all types of thinking skills from the most basic to the level of critical thinking skill [1]-[5]. 2013 curriculum requires teachers to use a scientific approach in learning, so that in the learning process, students are required to go through the process of observing, asking, trying, associating, and communicating. [6]-[9]. The use of a scientific approach can make students become interested in learning if it is helped by the use of interesting media, such as interactive module.

The application of a learning approach that is not accompanied by the application of an appropriate learning model will not have a maximum effect on student achievement [10]-[13]. Especially in subjects that are considered difficult, such as physics, which emphasizes calculating skills [14]. This is indicated by the learning outcomes in physics subject which tend to be low and below the minimum standard. The use of teaching media is an alternative to improve critical thinking skills [15]. Teaching materials that are preferred by teachers and students are electronic teaching materials that are practical and easy to use [16]. One of the teaching materials that are often used in school is the school printed module and school printed books, so it is necessary to have an electronic and easyto-use teaching material.

Along with the development of technology and the increasing use of electronics, smartphones that are getting more sophisticated from year to year can become a medium of learning. Thus, the use of electronic teaching materials such as e-modules which are practical and easy to use tends to attract students and teachers more.[15]. Based on preliminary research, the need for e-module teaching materials that use smartphones reaches a percentage of $86 \%$. The tendency of students to use cellphones makes students more interested in e-modules rather than print modules. Based on student responses about the teaching materials used, the teacher only provides printed teaching materials such as printed books, study sheets, and printed modules, so that students are less interested in learning which causes low learning outcomes [17]. In other words, students' skills in critical thinking are also weak [18].

The advantages of e-module compared to print module are that it is more interactive, not only displaying images but also audio, video, and animation, equipped with formative quizzes, and can be accessed via smartphones. [19]. Learning using e-modules is more flexible, because it can be accessed anywhere. This advantage helps students to be more active and independent [20]. The use of e-modules which are developed with the flipped classrom approach makes this e-module more special than other e-modules.

It is believed that the use of e-modules with a flipped classroom approach that is integrated with STEM will attract students' interest, because in STEM, there is an integration of science, technology, engineering, and mathematics which will make emodule more attractive. This e-module includes science that prioritizes analysis of natural phenomena, the use of technology such as experiments using Phet Simulation that is more practical and easier than the laboratory activites, engineering activities such as designing simple tools that can foster conceptual understanding and critical thinking skill [21], while mathematics in the e-module contains questions and evaluations because physics learning cannot be separated from calculations [22]. Learning that is integrated with STEM can improve student memory The types of questions given to students are in the form of questions that can train and measure critical thinking skills, this not only affects students' thinking skills, but also explores students' potential to be more independent in 
learningmake students have independent and critical thinking skills in understanding concepts [23], [24].

\section{METHOD}

The method in this research is a descriptive survey with data collection methods using a questionnaire conducted online (google form). The sample in this study amounted to 15 physics teachers in Lampung Province and 30 high school students in one of the schools in Bandar Lampung, teachers and students were presented with various questions regarding the need for electronic teaching materials that were practical and easy to use. The questions in the questionnaire are intended to see the need for teaching materials that can improve critical thinking skills. This questionnaire contains questions with the type of Likert scale rating which has criteria (4) Very necessary, (3) necessary, (2) fair, (1) unnecessary [25]. The response data obtained were then analyzed using quantitative descriptive analysis and presented as a percentage $(\%)$.

\section{RESULTS AND DISCUSSION}

Based on the results of the questionnaire analysis, the teacher stated that e-module using the STEM-integrated flipped classroom approach to improve critical thinking skills is needed. Several teachers also gave input that this e-module should contain a variety of interesting learning content, such as videos, animations, and illustrated pictures. Besides, this e-module also contains all STEM stages.

Advances in technology make education even more in need of teaching materials that are easy to use and effective. Table 1 is the data from the analysis of the needs of teachers and students.

Table 1. Results of A Questionnaire on Teacher Needs About E-modules Using The STEM Integrated

\begin{tabular}{|c|c|c|c|}
\hline \multicolumn{4}{|c|}{ Flipped Classroom Approach } \\
\hline No & Rated Aspect & Conclusion & Percentage \\
\hline 1 & Teaching material used in school & $\begin{array}{c}\text { Printed book/printed } \\
\text { module/printed } \\
\text { student worksheet }\end{array}$ & $75 \%$ \\
\hline 2 & The attractiveness of printed teaching materials & Less attractive & $43 \%$ \\
\hline 3 & Student learning outcomes & Low & $45 \%$ \\
\hline 4 & Electronic teaching materials & Very needed & $84 \%$ \\
\hline 5 & E e-modules & Needed & $86 \%$ \\
\hline 6 & Practicality of e-modules & Practical & $73 \%$ \\
\hline 7 & E-module containing videos about physics & Needed & $73 \%$ \\
\hline 8 & Contains interesting images & Needed & $66 \%$ \\
\hline 9 & Equipped with various charts & Needed & $46 \%$ \\
\hline 10 & Contains learning topics & Needed & $73 \%$ \\
\hline 11 & There is a competency test in the e-module & Needed & $53 \%$ \\
\hline 12 & Equipped with study instructions / instructions for use & Needed & $66 \%$ \\
\hline 13 & $\begin{array}{l}\text { E-modules must use clear, effective, and unambiguous } \\
\text { language }\end{array}$ & Needed & $73 \%$ \\
\hline 14 & E-module should provide practicum simulation & Needed & $73 \%$ \\
\hline 15 & The students' low critical thinking skills & Low & $36 \%$ \\
\hline 16 & $\begin{array}{l}\text { Questions/ Exercise that can measure critical thinking } \\
\text { skills }\end{array}$ & Needed & $76 \%$ \\
\hline
\end{tabular}

Based on Table 1, it was known that the teacher's response to the need for e-module teaching material reached a percentage of $86 \%$, which means that teachers really need teaching material in the form of e-module. Completeness of student learning outcomes

180 Indonesian Journal of Science and Mathematics Education ( I J S M E ) 
only reached $45 \%$ with low criteria. The low of student learning outcomes were one of the triggers for the need for new teaching materials that are practical and effective to improve critical thinking skills. Teachers expected an e-module that contains video content about physical phenomena, contains pictures, graphics, contains exercises, contains short material, contains competency tests, study instructions, and uses language that is easy to understand. Based on the questionnaire it was also known that the low critical thinking skills of students reached a percentage of $36 \%$ with low criteria. Based on 21st century skills, one of the learning outcomes is that students must have critical thinking skills, so, the e-module teaching media must be complemented with questions that can train critical thinking skills.

The results of student responses related to the need for e-modules to improve critical thinking skills show that students really need electronic teaching materials that are practical and easy to use, these results can be seen in Table 2 .

Table 2. The Results of Student Responses Related to The Need for STEM Integrated E-module

\begin{tabular}{|c|c|c|c|}
\hline No & Statements & Conclusion & Percentage \\
\hline 1 & Teaching materials used by the teacher & $\begin{array}{l}\text { Printed book, student } \\
\text { worksheet, power point }\end{array}$ & $67 \%$ \\
\hline 2 & The need for easy-to-use teaching media & Needed & $75 \%$ \\
\hline 3 & Electronic teaching media is needed & Needed & $83 \%$ \\
\hline 4 & A practical e-module is required & Needed & $78 \%$ \\
\hline 5 & Expected e-module design & $\begin{array}{l}\text { Interesting and contains video } \\
\text { about physics phenomena }\end{array}$ & $78 \%$ \\
\hline 6 & Contains interesting images & Needed & $74 \%$ \\
\hline 7 & Equipped with various charts & Needed & $63 \%$ \\
\hline 8 & Equipped with exercises & Needed & $78 \%$ \\
\hline 9 & Contains short material & Needed & $78 \%$ \\
\hline 10 & Contains competency test & Needed & $65 \%$ \\
\hline 11 & Equipped with study instructions & Needed & $82,7 \%$ \\
\hline 12 & Use easy-to-understand & Needed & $75 \%$ \\
\hline 13 & Contains practice simulations & Needed & $67 \%$ \\
\hline 14 & $\begin{array}{l}\text { Contains questions to train critical thinking } \\
\text { skills }\end{array}$ & Low & $36 \%$ \\
\hline 15 & $\begin{array}{l}\text { Exercises to measure and practice critical } \\
\text { thinking skills }\end{array}$ & Needed & $82 \%$ \\
\hline
\end{tabular}

Based on Table 2, the results of the student needs analysis on e-modules state that, so far teachers have only used printed teaching materials in the form of student worksheets and printed books, while the media used are only Power Points, teachers have not used electronic-based media such as e-modules. The student's need for teaching media reaches $75 \%$, which means that electronic teaching media is needed because it is easy and practical to use at any time. The media design needed by students includes content in the form of videos, contains interesting pictures, graphics, contains short material, contains competency tests, contains learning instructions, uses language that is easy to understand, and contains practical simulations. At the point of students' critical thinking ability, it only reached a percentage of $36 \%$ which means it is still low. The low ability of students to think critically is one of the reasons for the low student learning outcomes, so that an effective question is needed to train students' critical thinking skills.

The use of technology to support learning creates motivation for teachers and students. Based on the results of teacher and student responses regarding the use of emodule, we found that teachers and students need e-module because e-module was 
considered easy to use and practical. In the use of teaching materials in school teachers only used printed modules that are not interactive. The practicality of e-module for teachers is one of the factors that made them to consider replacing printed modules into electronic teaching materials, based on the results of the responses, $78 \%$ of teachers stated that they were considering changing the print module to an electronic module, and $73 \%$ of students stated that they had an electronic module rather than a print module. The use of technology can increase the efficiency and effectiveness of the learning process [26]-[30]. The advantages of the electronic module compared to the print module are that it is more interactive and able to display images, audio, video and animation and e-module is also equipped with a formative test/quiz that trains students to respond quickly.

The e-module design that is needed by teachers and students is an e-module containing videos that present short videos on physical optics material which is considered a difficult topic. In recent years, Flipped Classroom has become one of the emerging technologies in education and might become the standard of learning practice to encourage students to actively learn. Learning using a flipped classroom involves students to participate actively to deepen the concepts outside the classroom, with no time limit, so that the flipped classroom trains students to be more independent in learning. So, when learning in class begins, students will understand more about the learning topics discussed. [31]. The teachers also believed that e-learning module that are integrated with STEM will be more practical to use. In addition, with STEM, students will have the opportunity to learn by utilizing Science concepts, utilizing Technology, learning to design (Engineering), and applying Mathematics, so that learning will become more memorable.

\section{CONCLUSION}

Based on the results of the response from the teachers and students' needs analysis, it can be concluded that e-module is an alternative for teachers as an easy and practical teaching media to improve critical thinking skills. $86 \%$ of physics teachers stated that they needed a STEM-integrated flipped classroom e-module, and $78 \%$ of students stated that they were interested in learning by using a STEM-integrated flipped classroom e-module. So it is clear that physics teachers and students in Lampung need e-modules with a flipped classroom approach and integrated STEM.

\section{REFERENCES}

[1] I. Suarsana and G. . Mahayukti, "Pengembangan e-modul berorientasi pemecahan masalah," vol. 2, no. 2, pp. 264-275, 2013.

[2] Y. F. Surya, "Penggunaan Model dan Pendekatan Pembelajaran Pendidikan Karakter Abad 21 pada Anak Usia Dini," J. Obs. J. Early Child. Educ., vol. 1, no. 1, p. 52, 2017.

[3] C. Dasgupta, A. J. Magana, and C. Vieira, "Investigating the affordances of a CAD enabled learning environment for promoting integrated STEM learning," Comput. Educ., vol. 129, pp. 122-142, 2019.

[4] A. J. Khoiriyah and H. Husamah, "Problem-based Learning: Creative Thinking Skills, Problem-solving Skills, and Learning Outcome of Seventh Grade Students," J. Pendidik. Biol. Indones., vol. 4, no. 2, pp. 151-160, 2018.

[5] M. A. B. Setambah, N. M. Tajudin, M. F. M. Yaakob, and M. I. M. Saad, "Adventure learning in basics statistics: Impact on students critical thinking," Int. J. Instr., vol. 12, no. 3, pp. 151-166, 2019.

[6] S. Yani, S. Agus, and W. Ismu, "Pengembangan modul pembelajaran menggunakan learning content development system materi gerak harmonik sederhana,"

182 Indonesian Journal of Science and Mathematics Education 
pembelajaran Fis., no. 1, pp. 87-99, 2016.

[7] M. J. S. N. S. M. E. Susilowati, "Pengembangan Pembelajaran Model Discovery Learning Berbantuan Tips Powerpoint Interaktif Pada Materi," vol. 6, no. 2, pp. 130-137, 2016.

[8] W. Maba, "Teachers' Perception on the Implementation of the Assessment Process in 2013 Curriculum," Int. J. Soc. Sci. Humanit. , vol. 1, no. 2, pp. 1-9, 2017.

[9] M. . Nur and A. Madkur, "Teachers' Voices on the 2013 Curriculum for English Instructional Activities," Int. J. English Educ., vol. 1, no. 2, pp. 119-134, 2014.

[10] D. Haryani, "Pembelajaran Matematika Dengan Pemecahan Masalah Untuk Menumbuhkembangkan Kemampuan Berpikir Kritis Siswa," Pros. Semin. Nas. Penelitian, Pendidik. dan Penerapan MIPA, no. 1980, pp. 121-126, 2011.

[11] A. Arda, S. Saehana, and D. Darsikin, "Pengembangan Media Pembelajaran Interaktif Berbasis Komputer Untuk Siswa Smp Kelas VIII," e-Jurnal Mitra Sains, vol. 3, no. 1, pp. 69-77, 2015.

[12] A. Gumrowi, "Meningkatkan Hasil Belajar Listrik Dinamik menggunakan Strategi Pembelajaran Team Assisted Individualization melalui Simulasi Crocodile Physics," J. Ilm. Pendidik. Fis. Al-Biruni, vol. 5, no. 1, p. 105, 2017.

[13] D. Ambarwati and A. Suyatna, "Interactive design for self-study and developing students' critical thinking skills in electromagnetic radiation topic," J. Phys. Conf. Ser., vol. 948, no. 1, 2018.

[14] S. Nur Hadi and A. Juliani Noor, "Keefektifan Kelompok Belajar Siswa Berdasarkan Sosiometri dalam Menyelesaikan Soal Cerita Matematika di SMP," EDU-MAT J. Pendidik. Mat., vol. 1, no. 1, pp. 60-67, 2013.

[15] K. W. B. Putra, I. M. A. Wirawan, and G. A. Pradnyana, "Pengembangan E-Modul Berbasis Model Pembelajaran Discovery Learning Pada Mata Pelajaran 'Sistem Komputer' Untuk Siswa Kelas X Multimedia Smk Negeri 3 Singaraja,’ J. Pendidik. Teknol. dan Kejuru., vol. 14, no. 1, pp. 40-49, 2017.

[16] Danang and Fausih, "Penggunaan E-Modul Interaktif Melalui Pembelajaran Berbasis Masalah Untuk Meningkatkan Pemahaman Konsep Sistem Saraf, Kemampuan Generik Sains Dan Berpikir Kritis.," J. Pendidik., vol. 1, pp. 1-7, 2016.

[17] B. Hartati, "Pengembangan Alat Peraga Gaya Gesek untuk Meningkatkan Keterampilan Berpikir Kritis Siswa SMA," J. Pendidik. Fis. Indones., vol. 6, pp. 128-132, 2010.

[18] F. Ririn and M. Mukarramah, "Pembelaran kooperatif tipe think talk write: pengaruhnya terhadap kemampuan berpikirkritis peserta didik SMK SMTI BANDARLAMPUNG," vol. 01, no. November, pp. 263-270, 2018.

[19] S. Riyadi and Qamar, "Efektivitas E-Modul Analisis Real Pada Program Studi Pendidikan Matematika Universitas Kanjuruhan Malang," Supremum J. Math. Educ. J., vol. 1, no. 1, pp. 26-33, 2017.

[20] H. El-Senousy and J. Alquda, "The Effect of Flipped Classroom strategy using Blackboard Mashup tools in enhancing achievement and Self- Regulated learning skills of university students," World J. Educ. Technol. Curr. Issues, vol. 6, no. 3, p. 144, 2017.

[21] S. Han, R. Rosli, M. M. Capraro, and R. M. Capraro, "The effect of Science, technology, engineering and mathematics (STEM) project based learning (PBL) on students' Achievement in four mathematics topics," J. Turkish Sci. Educ., vol. 13, no. Specialissue, pp. 3-30, 2016.

[22] W. E. Dugger, "Evolution of STEM in the United States," 6Th Bienn. Int. Conf. 
Technol. Educ. Res., no. March, pp. 1-8, 2010.

[23] M. M. carpraro Ayse tube oner, Robert m Capraro, "The Effect of T-STEM Designation on Charter Schools: A Longitudinal Examination o f Students , Mathemat," vol. 2, no. August, pp. 80-96, 2016.

[24] F. da C. Carbogim, L. B. de Oliveira, É. T. de Mendona, D. A. Marques, D. B. de C. Friedrich, and V. A. de A. Püschel, "Teaching critical thinking skills through problem based learning," Texto e Context. Enferm., vol. 26, no. 4, pp. 1-10, 2017.

[25] S. Arikunto, Prosedur Penelitian Suatu Pendekatan Praktik. Jakarta: Rineka Cipta, 2013.

[26] T. N. Utami, A. Jatmiko, and S. Suherman, "Pengembangan Modul Matematika dengan Pendekatan Science, Technology, Engineering, And Mathematics (STEM) pada Materi Segiempat," Desimal J. Mat., vol. 1, no. 2, pp. 165-172, 2018.

[27] R. M. Vieira and C. Tenreiro-Vieira, "Fostering Scientific Literacy and Critical Thinking in Elementary Science Education," Int. J. Sci. Math. Educ., 2016.

[28] R. J. Schlegel, S. L. Chu, K. Chen, E. Deuermeyer, A. G. Christy, and F. Quek, "Making in the classroom: Longitudinal evidence of increases in self-efficacy and STEM possible selves over time," Comput. Educ., vol. 142, no. June 2018, p. 103637, 2019.

[29] A. Saregar et al., "Temperature and heat learning through SSCS model with scaffolding: Impact on students' critical thinking ability," J. Educ. Gift. Young Sci., vol. 6, no. 3, pp. 39-52, 2018.

[30] K. Yang, T. Wang, and M.-H. Chiu, "Study The Effectiveness of TechnologyEnhanced Interactive Teaching Environment on Student Learning of Junior High School Biology," Eurasia J. Math. Sci. Technol. Educ., vol. 11, no. 2, pp. 263-275, 2015.

[31] Duyu, Arslan, and Ali, "The Effect of Flipped Classroom on the Academic Achievement and Attitude of Higher Education Students," Word J. Educ., vol. 8, no. 4, pp. 170-176, 2018. 